\title{
Aspiring to an altered stable state: rebuilding of bay scallop populations and fisheries following intensive restoration
}

\author{
Stephen T. Tettelbach ${ }^{1, *}$, Bradley J. Peterson ${ }^{2}$, John M. Carroll ${ }^{2,4}$, \\ Bradley T. Furman ${ }^{2}$, Scott W. T. Hughes ${ }^{3}$, Jason Havelin ${ }^{1,3}$, James R. Europe ${ }^{1}$, \\ Dennis M. Bonal ${ }^{1}$, Andrew J. Weinstock ${ }^{1}$, Christopher F. Smith ${ }^{3}$ \\ ${ }^{1}$ LIU-Post, Brookville, NY 11548, USA \\ ${ }^{2}$ Stony Brook University, Southampton, NY 11968, USA \\ ${ }^{3}$ Cornell Cooperative Extension of Suffolk County, Southold, NY 11901, USA \\ ${ }^{4}$ Present address: University of North Carolina Wilmington, Wilmington, NC 28403, USA
}

\begin{abstract}
Intensive efforts to restore bay scallop Argopecten irradians irradians populations and fisheries in the Peconic Bays of eastern Long Island, New York, USA, were begun in 2006, following a 12 yr period during which commercial fishery landings averaged 1 to $2 \%$ of historical levels seen prior to 1985 to 1995 brown tide algal blooms. Compared to 2005 to 2006, natural population densities of $0+$ yr scallops in fall increased $16 \times$ by 2007 in Orient Harbor $(\mathrm{OH})$, the focus of our restoration efforts; by 2009, densities in $\mathrm{OH}$ and other, unplanted, embayments had increased by $110 \times$ and up to $331 \times$, respectively. Spatial and temporal patterns paralleled those documented for larval recruitment; highly significant correlations between commercial harvest levels and both baywide larval settlement and juvenile benthic densities were revealed. Official fishery landings were $13 \times$ those of pre-restoration levels by 2010 and have remained relatively stable through 2013. Following commencement of restoration, dockside revenues and economic benefit to the regional economy have increased by $\sim$ US $\$ 2$ million and \$20 million, respectively; our calculations suggest that these figures are $40 \%$ of actual numbers. Population resurgence is not correlated to temporal changes in predator populations or submerged aquatic vegetation cover. We conclude that rebuilding of Peconic bay scallop populations and fisheries has been driven by dramatic increases in bay scallop larval supply emanating from our intensive restoration efforts. By definition, we cannot say that Peconic bay scallops have attained an alternate stable state, but it is clear that dramatic increases in populations, fishery landings, and economic value are possible in just a few years.
\end{abstract}

KEY WORDS: Scallop · Argopecten · Restoration · Metapopulation · Fishery · Economic benefits · Submerged aquatic vegetation

Resale or republication not permitted without written consent of the publisher

\section{INTRODUCTION}

Ecological theory predicts that animal populations or communities may exist at multiple stable states (Lewontin 1969, Roughgarden \& Iwasa 1986, Petraitis \& Dudgeon 2004). Beisner et al. (2003) categorized 2 mechanisms by which shifts to alternative states in marine communities may occur, via significant perturbations to: (1) 'state variables' (e.g. density of a given population) or (2) environmental parameters (e.g. nutrients) that dictate how state variables behave and interact, and thus might affect basic demographic processes, carrying capacity, or the responses of predator populations. The effects of 
such perturbations may be reflected in cyclic, multidecadal fluctuations in marine animal abundance driven by food availability (Chavez et al. 2003), predation (Neave 1953, Paine 1966), or atmospheric forcings (Menge et al. 2011, Kimmel et al. 2012). In other instances, marine populations, communities, or ecosystems have suffered catastrophic impacts due to more stochastic disturbances such as hurricanes (Gunderson 2000), volcanism (Vermeij 1995), harmful algal blooms (Cosper et al. 1987, Summerson \& Peterson 1990), coral bleaching (van Oppen \& Lough 2009), or epizootics (Lessios et al. 1984); overharvesting may have a comparable effect (Peterson 2002, Orensanz et al. 2006).

The most basic type of dynamic leading to alternate states in populations is where Allee effects (= depensation) are operating (Knowlton 2004). In the case of free-spawning invertebrates, the impacts of low abundance/density exhibited by 'collapsed' populations may be reflected in reduced fertilization success and recruitment limitation (Peterson \& Summerson 1992, Levitan \& Petersen 1995, Peterson et al. 1996, Arnold et al. 1998, Liermann \& Hilborn 2001). Recovery of collapsed populations through natural processes may be very slow and, regardless of whether populations exhibit formal alternative states or not, can only be effected more rapidly via some fundamental change in conditions (Knowlton 2004). This recovery may take place if the population is altered directly (e.g. by actively increasing population density) or the landscape in which the population exists is changed (Beisner et al. 2003, Knowlton 2004). Once the community has reached a new domain, it should remain there unless another, large(r) perturbation occurs (Beisner et al. 2003).

The goal of ecological restoration programs is to return populations or ecosystems to some prior state of better condition, i.e. they aspire to an altered stable state: one that remains after the perturbation is removed (Connell \& Sousa 1983). Feedbacks in degraded systems, however, may make them resilient to restoration, so successful approaches often require bold and innovative management that disrupts feedbacks and addresses prioritized constraints (Suding et al. 2004). A transition between alternative states may occur as a result of enhancing factors favorable for recruitment (Knowlton 2004). In the context of shellfish restoration, it may be possible to rebuild multiple local populations by rebuilding key source populations for larval production, provided the original cause of the population decline no longer persists (Arnold et al. 2005). Numerous approaches have been attempted to enhance recruitment of shellfish populations, including provision of suitable habitat/substrate, larval and juvenile (seed) release, establishment of spawner sanctuaries, and broodstock relay between basins (Ventilla 1982, Peterson et al. 1996, Goldberg et al. 2000, Geraldi et al. 2013). Often, enhancement efforts are short-lived, or unsuccessful for other reasons (Peterson \& Lipcius 2003), and populations do not reach an altered stable state.

In the Peconic Bays of eastern Long Island, New York, USA, populations of bay scallops Argopecten irradians irradians collapsed following a series of brown tide algal blooms of Aureococcus anophagefferens from 1985 to 1995. Despite the absence of brown tide blooms since 1995, scallop populations remained at very low levels over the next $12 \mathrm{yr}$. We hypothesized that low scallop density/abundance resulted in impaired fertilization success and recruitment limitation, and attempted to jump-start the rebuilding of natural populations by increasing larval supply; this was done via high-density plantings of several million hatchery-reared animals in spawner sanctuaries (Tettelbach \& Smith 2009, Tettelbach et al. 2013). Following commencement of this intensive restoration, we documented dramatic increases in bay scallop larval settlement (up to $32 \times$ higher after 4 yr) that were driven by our restoration efforts (Tettelbach et al. 2013).

Enhancement of larval supply does not necessarily translate to higher levels of recruitment to benthic populations, as this is governed by both pre- and postsettlement processes. Efforts to restore scallop and other bivalve mollusk populations typically focus on pre-settlement processes by building spawning stock and boosting reproductive output (Peterson et al. 1996, Goldberg et al. 2000) as there is much less control possible over critical post-settlement processes. Mortality of post-set juvenile invertebrates is generally very high in the days to weeks postsettlement, and can be caused by both abiotic factors (hydrodynamics, salinity, temperature, hypoxia/anoxia) and biotic interactions (competition and predation: Eggleston \& Armstrong 1995, Gosselin \& Qian 1997, Hunt \& Scheibling 1997). Ultimately, in order for restoration efforts to successfully build populations to a higher stable state, enhanced larval supply must result in higher recruitment to benthic populations. Additionally, stock rebuilding is usually contingent upon sustainable harvest practices. The bay scallop fishery, however, is atypical in that there are rarely any quotas on total harvest or targeted levels of sustainable landings, but overfishing is not commonly considered to be a causal factor in population declines (Belding 1910, Orensanz et al. 2006). This is due to the 
unusual life history of bay scallops, where, for the northern subspecies, adults usually spawn in the spring/ summer at an age of $\sim 1 \mathrm{yr}$ and the great majority ( 80 to $>90 \%$ ) die in the winter/early spring before they can spawn in a second year (Belding 1910). Harvests, which commence in mid- to late fall, are thus almost always dependent on a single year class and may fluctuate wildly, further reflecting the importance of sustained recruitment.

In this paper, we document a resurgence in benthic bay scallop populations and commercial fishery landings/ economic value following commencement of our intensive restoration efforts. We examine whether increases in population densities are correlated to (1) temporal changes in predator abundance, (2) environmental parameters, or (3) increased larval recruitment. We also examine whether higher commercial fishery landings correlate with increases in larval recruitment and/or 0+ yr scallop densities.

\section{MATERIALS AND METHODS}

\section{Monitoring of scallop and predator abundance}

Populations of Argopecten irradians irradians are typically comprised of just 2 year-classes $(0+\mathrm{yr}=$ juvenile or seed, $1+\mathrm{yr}=$ adult); the latter are readily differentiated, as their shells possess a raised annual growth ring (Belding 1910). In this paper, we report 8 yr of data for fall (October to early November) abundance of the 2 year-classes: juveniles $\geq 15 \mathrm{~mm}$ (the minimum size routinely documented during visual dive surveys) and adults, just prior to the start of the commercial season; these data encompass 2005 and 2006 (prior to commencement of intensive restoration in Orient Harbor [OH]) and 2007 to 2012 (ongoing restoration period; Tettelbach et al. 2013; Table 1). In 2005 and 2006, fall surveys were not conducted in Great Peconic Bay (GPB) or Flanders Bay (FB), and only 1 site was sampled in $\mathrm{OH}$ in fall 2006. Therefore, we utilized survey data for these areas from spring 2006 and/or 2007 and pooled respective data with those for the prior fall. This was not done in other areas/years where fall sampling was much more extensive. Spring population data for 2005 to 2010 were presented by Tettelbach et al. (2013).
Scallop densities were documented in visual surveys conducted by scuba divers at up to 23 sites per season, in a total of 7 embayments (Fig. 1, and see Supplement 1, available at www.int-res.com/articles/suppl/ m529p121_supp.pdf). At each site, from 2 to 4 (but usually 3) $50 \mathrm{~m}$ transects were deployed from a central point, with the first toward the direction of the prevailing wind and others at equidistant angles; this approach was precluded at 3 shallow sites, where 2 transects were run parallel to shore and 1 perpendicular, running offshore. Transect lines were swum out to their respective ends, then counts/collections of all live scallops, cluckers (recently dead scallops with articulated valves), and potential predators (see below) were made on the return swim within a $1 \mathrm{~m}$ wide swath to the right of the transect line. Sampling site depths ranged from 1.3 to $6.3 \mathrm{~m}$ at mean low water, which is where the majority of scallop populations occur (Tettelbach et al. 2013), in a range of typical bay scallop habitats (Supplement 1). Surveys conducted in $\mathrm{OH}$, Hallock Bay (HB), Northwest Harbor (NW), Southold Bay (SB), and Hog Neck Bay (HN) (Fig. 1, Supplement 1) were done at larval recruitment monitoring sites (Tettelbach et al. 2013). Surveys conducted in FB and GPB were conducted at historical fishing grounds.

Potential predators (crabs, gastropods, sea stars, finfish: Tettelbach 1986, Weinstock 2010, Carroll et al. 2010) of scallops $\geq 15 \mathrm{~mm}$, were also enumerated in transect surveys. Tallies included predators that were readily visible at the sediment surface, obviously buried (e.g. whelks), or within/under sparse submerged aquatic vegetation (SAV). We did not sort through dense (>50\% cover) macroalgae, as predator densities are typically low here (S. Tettelbach unpubl. data), or excavate shell hash; densities of 


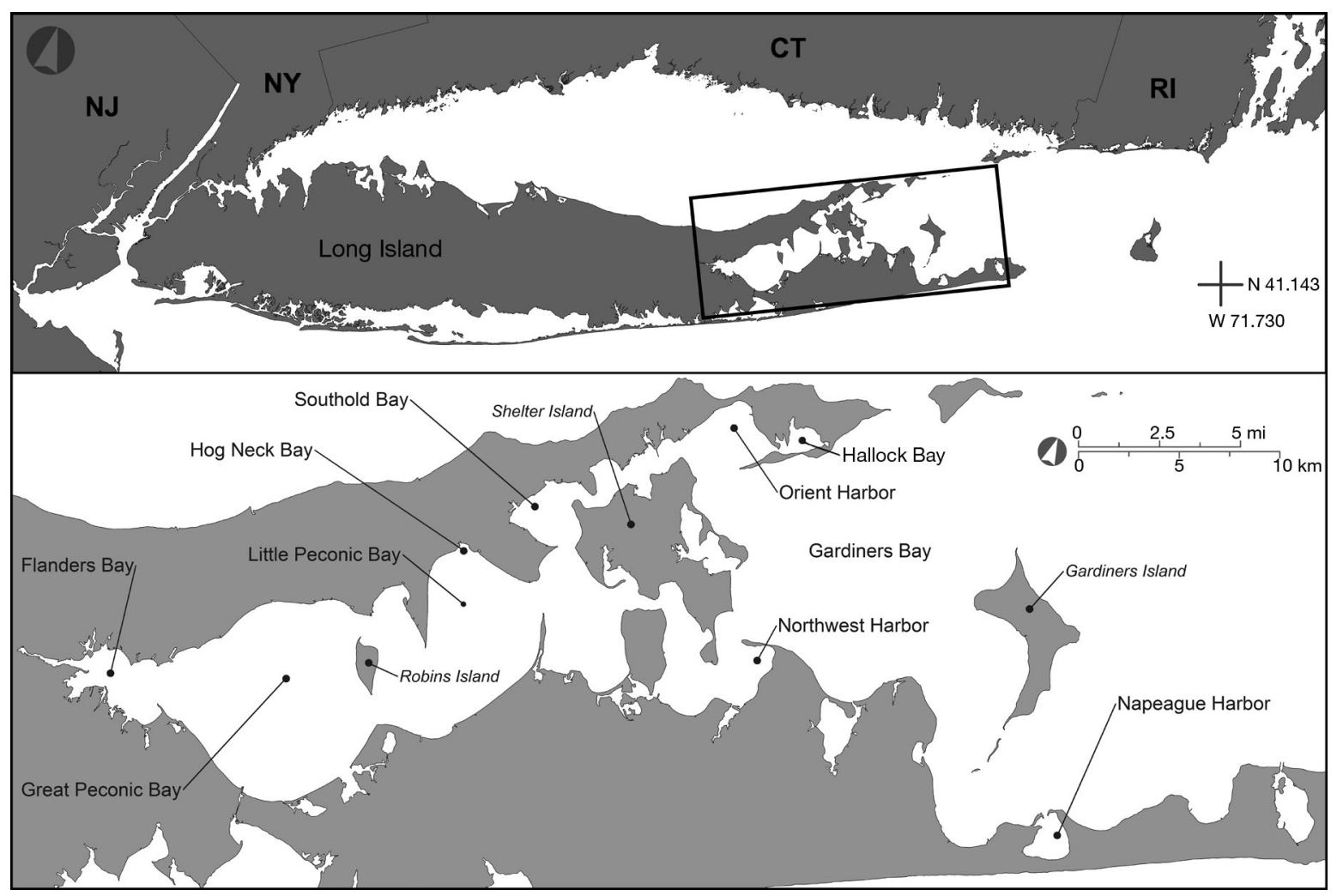

Fig. 1. Northeastern US (NJ: New Jersey, NY: New York, CT: Connecticut, RI: Rhode Island), showing location of the Peconic Bays in eastern Long Island, NY, and other areas noted throughout the main text

mud crabs Dyspanopeus sayi were thus undoubtedly underestimated (Carroll et al. 2010).

\section{Monitoring of environmental parameters}

Tettelbach et al. (2013) previously demonstrated that increased larval recruitment following the commencement of restoration was not correlated to coincidental changes in water temperature, salinity, rainfall, chlorophyll $a$, or total particulate nitrogen $(p>$ 0.67 for all), and so we did not reexamine these factors here; rather, we investigated whether observed scallop densities in fall (October/November) were correlated to \% SAV cover or relative current speed. Average percent cover of dominant SAV was estimated visually by divers during transect surveys. A relative index of current flow (high or low: Knights \& Walters 2010) was derived for each survey site (over a 3 d period in July 2013) by calculating percent weight loss of 3 replicate Hydro-Stone ${ }^{\circledR}$ (USG) gypsum cement balls (mixed according to the manufacturer's specifications: $65 \mathrm{~g}$ water to $100 \mathrm{~g}$ powder) affixed to wooden dowels and deployed $\sim 0.5 \mathrm{~m}$ above the sediment surface for $49.73 \pm 0.2 \mathrm{~h}$, with subsequent air drying for $\sim 72 \mathrm{~h}$.

\section{Commercial fishery landings}

As the ultimate goal of our restoration program has been to rebuild the Peconic bay scallop fishery, we also report commercial landings (NYSDEC 2014) for pre-restoration and restoration periods; recreational landings are not officially reported but are minimal compared to commercial landings. We calculated the economic benefits to baymen (dockside value) that resulted from increased Peconic scallop harvests following commencement of scallop restoration, via Eq. (1):

$\Sigma$ (annual dockside value restoration $_{\text {- average annual }}$ dockside value pre-restoration)

2008 to 2013 represents the restoration period; 2008 was the first year when any potential harvest increase might have resulted from our first intensive plantings of scallop brood stock in $\mathrm{OH}$ in 2006 (with subsequent spawning in 2007 and growth of $0+\mathrm{yr}$ 
offspring to a harvestable adult by November 2008). Average annual harvest during the pre-restoration period (1996-2007) was $1512 \mathrm{~kg}$ (NYSDEC 2014).

A second estimate of increased dockside value for Peconic harvests, Eq. (2), was calculated since baymen now sell more scallops directly to restaurants and other private buyers than in years past; these figures do not get reported to NYSDEC (S. Ritchie pers. comm.). This supposition, combined with vessel counts and estimated average landings per vessel during the first $2 \mathrm{wk}$ of recent seasons (when much of the harvest occurred), led to the conclusion that reported NYSDEC landings were $\sim 40 \%$ of actual harvest levels.

$$
\begin{gathered}
\Sigma 2.5 \text { (annual dockside value } \\
\text { dostoration } \\
\text { dockside value } \\
\text { pre-restoration })
\end{gathered}
$$

To be conservative in our estimate, the average pre-restoration harvest was also multiplied by 2.5 .

An estimate was also calculated for total increase in seafood product revenue resulting from increased Peconic scallop landings (increases in sales price, plus profit, along the commercial seafood processing chain: processing, wholesale/distribution, retail/groceries, restaurants) using a $9.88 \times$ multiplier derived from Kroeger (2012); this was applied to dockside values calculated via Eqs. (1) and (2). None of the above economic metrics was adjusted for inflation.

\section{Statistical analyses}

We examined spatial and temporal trends in abundance of $0+$ and $1+$ yr scallops, during fall population surveys, via respective 2-way ANOVAs on ranks (as data were non-normal), with embayment and year as factors. Subsequent 1-way ANOVAs explored these relationships further: annual (2005-2012) differences in mean densities of $0+\mathrm{yr}$ and $1+\mathrm{yr}$ scallops during fall surveys were compared for all 7 embayments combined, as well as for individual embayments; where significant, multiple comparisons were performed via the Tukey HSD method.

Temporal trends in rank-transformed total predator density in each of the 7 embayments, for 2005 to 2012, were examined via a Type III 2-way ANOVA to test for the main and interactive effects of season (spring or fall) and restoration status (pre- or postrestoration). Transects were treated as replicates and aggregated at the system level (i.e. Peconic-wide). Site-specific patterns were investigated using separate re-sampling simulations of 1-way ANOVAs on predator densities with restoration status as a fixed factor. Spatial and temporal sampling was unbalanced $(\mathrm{OH}$ was the most sampled embayment [31\% of all samples], and the pre-restoration period was characterized by more than twice as many spring observations as in the fall, while the reverse was true for the restoration period [pre-restoration: $\mathrm{n}=22$ spring, 10 fall; restoration: $\mathrm{n}=78$ Spring, 123 fall]). This bias was consistent across all Peconic embayments (pre-restoration: $\mathrm{n}=102$ spring, $37 \mathrm{fall}$; restoration: $\mathrm{n}=259$ spring, 366 fall). Therefore, predator data were pooled by season prior to permutation and re-sampled with replacement to preserve the original sampling density and degree of seasonal imbalance. The magnitude of the observed $F$-statistic was thereafter compared to the empirical distribution following 10000 iterations.

An additional 1-way ANOVA of total predator density versus year was done to compare our unpublished 'historical' (1988-1990) data to pre-restoration (2004-2005) predator abundance data obtained at the SWG (State Wildlife Grant) site in NW (Tettelbach et al. 2011). These data were collected in replicate $1 \mathrm{~m}^{2}$ quadrats during years when this location was planted with hatchery-reared scallops. To account for anticipated seasonality in predator abundance, monthly means were matched between the 'historical' and pre-restoration periods; October was considered equivalent to November to maintain sampling balance. In all cases, transformations were made to satisfy ANOVA assumptions prior to analysis.

Limited percent coverage data for SAV prior to restoration did not permit an assessment of temporal changes, but we examined whether fall densities of 0+ and 1+ yr scallops in 2009 to 2012 were related to SAV coverage via 1-way ANOVA (where scallop density data were ranked and SAV transects treated as pseudoreplicates); \% SAV cover data were grouped into 2 categories $(<2 \%=$ unvegetated, $\geq 2 \%$ = vegetated). A 2-way, Type III interactive ANOVA was performed to examine ranked fall seed densities versus relative current flow (high or low) and restoration status. This analysis was run with and without the site at Hay Beach $(\mathrm{OH})$, as this was our only sampling site where eelgrass existed.

The relationship between larval recruitment (spat bag $^{-1}$ ) versus fall density of $0+$ yr scallops was examined, as this is the most direct way to evaluate the contribution of increased larval supply, because it does not factor in the critical overwintering period (Tettelbach et al. 1990, Tettelbach \& Wenczel 1993); monitoring methods and values for spat (post-set) abundance can be found in Tettelbach et al. (2013). Relationships between mean annual abundance of 
spat, $0+$ yr juveniles, and 1+yr adults of the same cohort (e.g. 2008 spat were matched up with $20080+$ yr juveniles and 2009 1+ yr adults) were analyzed for each embayment using Pearson correlations. When significant relationships were found, linear and nonlinear (ln) regressions were fit to whole-estuary data to determine whether there were predictive relationships; this was also done for both spat abundance and $0+$ yr scallop density versus commercial Peconic bay scallop landings in the following year. Models were compared using Akaike's information criterion (AIC); those with the lowest AIC score were considered to have the best fit.

\section{RESULTS}

\section{Spatial and temporal trends in scallop abundance}

Fall densities of $0+$ yr bay scallops in natural populations increased dramatically (up to $331 \times$ ), relative to pre-restoration levels, following commencement of intensive restoration (Table 2, Fig. 2). Initially, the embayment-level increase was most significant in $\mathrm{OH}$, the site of our primary restoration efforts, where mean $0+$ yr densities were $16.2 \times$ and $33.3 \times$ higher in 2007 and 2008, respectively. By fall 2009, 0+ yr densities had increased dramatically in $\mathrm{OH}(110 \times)$, in 2 other embayments where spawns of successful plantings occurred (HB: 34×, FB: 331×), and in embayments where no restoration had been conducted (NW: $211 \times$, GPB: $314 \times$ ). The highest seed densities, relative to pre-restoration levels, in $\mathrm{HN}(7.2 \times)$ and $\mathrm{SB}$ $(32.7 \times)$ occurred in 2011 and 2012, respectively.

Fall densities of 1+ yr scallops were markedly higher in $\mathrm{OH}$ by 2008 and, in 2011, reached as high as $21 \times$ relative to 2005-2006 (Table 2). Despite these increases, there were few differences in Tukey HSDs, indicating that statistical power may have been an issue for a number of post hoc contrasts. The highest observed adult scallop densities were seen in GPB, but we have no data from 2005-2006 with which to make comparisons. Adult densities at our sites in $\mathrm{HB}, \mathrm{NW}$, and $\mathrm{SB}$ showed only modest increases or declined slightly following commencement of restoration.

\section{Spatial and temporal trends in predator abundance}

Total predator density (Fig. 3), as measured via transect sampling, was not significantly affected by restoration status $\left(F_{1,760}=2.75, \mathrm{p}=0.10\right)$; however, significant seasonal $\left(F_{1,760}=48.88, \mathrm{p}<0.001\right)$ and season $\times$ restoration $\left(F_{1,760}=4.70, \mathrm{p}=0.04\right)$ effects were found. The latter indicated that fall predator densities may have been elevated during the restoration period. Site-specific simulations found that the magnitude of the restoration effect exceeded that which was possible by random permutation in only 1 of the 7 bays examined (OH: p = 0.004). Again, elevated predator densities during the restoration period were suggested. In light of the temporal imbalance in sampling frequency (noted above) and given that predator densities were routinely higher in the fall, 2 interpretations of the apparent restoration effects can be made: (1) fall predator densities rose concurrently with restoration, or (2) systematic bias in seasonal sampling effort resulted in an artifactual restoration signal. We posit the second explanation to be more parsimonious, and conclude that no bulk shifts in predator densities occurred as a result of, or concomitant with, the onset of restoration; this finding was consistent with the lack of difference between historical and pre-restoration predator surveys in NW $\left(F_{1,7}=2.28, \mathrm{p}=0.17\right)$.

\section{Relationship of scallop abundance to environmental parameters}

Fall density (from 2009 to 2012) of 0+ and 1+ yr scallops did not differ with respect to \% SAV cover $\left(F_{1,79}=1.86, \mathrm{p}=0.176 ; F_{1,79}=0.002, \mathrm{p}=0.966\right.$, respectively). Bay-wide fall density of juvenile scallops was significantly higher after restoration commenced, compared to the pre-restoration period (all sites: $F_{1,41}=21.85, \mathrm{p}<0.0001$; excluding the Hay Beach eelgrass site: $F_{1,39}=12.33, \mathrm{p}=0.0011$ ), but did not differ with respect to relative current flow (all sites: $F_{1,41}=0.58, \mathrm{p}=0.449$; excluding the Hay Beach eelgrass site: $F_{1,39}=0.54, \mathrm{p}=0.47$ ) or restoration status $\times$ flow interaction (all sites: $F_{1,41}=3.35, \mathrm{p}=0.074$; excluding the Hay Beach eelgrass site: $F_{1,39}=2.77$, $\mathrm{p}=0.10)$.

\section{Relationship of larval supply, juvenile $(0+y r)$, and adult $(1+y r)$ abundance}

Different relationships between larval supply (spat) and fall density of $0+$ yr scallops were exhibited in different embayments. In both $\mathrm{OH}$ and SB there were strong positive, linear relationships between juvenile scallop densities and mean larval recruitment $(r=0.736, p=0.038$ and $r=0.881, p=$ 
Table 2. Mean fall density of (A) juvenile $(0+\mathrm{yr})$ and (B) adult $(1+\mathrm{yr})$ bay scallops Argopecten irradians irradians in different embayments within the Peconic bay system, Long Island, New York, USA, from 2005 to 2012. (i) Tukey HSD multiple comparisons of scallop density for embayments combined (embayments as in [ii]), following respective 2-way ANOVAs (0+ yr scallops: $F=34.45$ for embayments, $\mathrm{p}<0.0001 ; F=78.99$ for years, $\mathrm{p}<0.0001 ; 1+$ yr scallops: $F=4.26$ for embayments, $\mathrm{p}=0.0002$; $F=7.82$ for years, $\mathrm{p}<0.0001)$. Years with different lower-case letters are significantly different $(\mathrm{p}<0.05)$. NS $=$ not surveyed. (ii) Tukey HSD multiple comparisons of annual mean scallop density within embayments shown (OH: Orient Harbor; HB: Hallock Bay; NW: Northwest Harbor; SB: Southold Bay; HN: Hog Neck Bay; GPB: Great Peconic Bay; and FB: Flanders Bay) for significant $(\mathrm{p}<0.05) 1$-way ANOVAs and percent change from the 2 years prior to initiation of intensive restoration in $\mathrm{OH}$ (2005-2006) compared to each of the 6 years of restoration (2007-2012). Lower case letters as in (i)

\begin{tabular}{|c|c|c|c|c|c|c|c|c|c|c|c|c|c|c|}
\hline \multirow[t]{2}{*}{$\begin{array}{l}\text { A. Juveniles } \\
\text { (i) }\end{array}$} & \multicolumn{8}{|c|}{ Multiple comparisons of mean $0+$ yr scallop density (ind. $\mathrm{m}^{-2}$ ) } & & & & & & \\
\hline & a & a & $\mathrm{b}$ & bc & $\mathrm{d}$ & $\mathrm{d}$ & $\mathrm{d}$ & dc & & & & & & \\
\hline \multirow[t]{2}{*}{ (ii) } & \multicolumn{8}{|c|}{ Mean no. $0+$ yr scallops $\mathrm{m}^{-2}$} & \multicolumn{6}{|c|}{$\begin{array}{l}\% \text { change in mean } 0+\text { yr scallop density } \\
(2005-2006) \text { to: }\end{array}$} \\
\hline & 2005 & 2006 & 2007 & 2008 & 2009 & 2010 & 2011 & 2012 & 2007 & 2008 & 2009 & 2010 & 2011 & 2012 \\
\hline $\mathrm{OH}$ & $\begin{array}{c}0.002 \\
\mathrm{a}\end{array}$ & $\begin{array}{c}0.031 \\
\mathrm{ab}\end{array}$ & $\begin{array}{c}0.268 \\
\mathrm{bc}\end{array}$ & $\begin{array}{l}0.550 \\
\mathrm{~cd}\end{array}$ & $\begin{array}{c}1.818 \\
\text { de }\end{array}$ & $\begin{array}{c}3.087 \\
\mathrm{e}\end{array}$ & $\begin{array}{c}2.034 \\
\text { de }\end{array}$ & $\begin{array}{c}2.811 \\
\text { de }\end{array}$ & 1524 & 3233 & 10918 & 18609 & 12227 & 16936 \\
\hline HB & 0.012 & 0.020 & 0.013 & 0.007 & 0.551 & NS & 0.004 & 0.0003 & -19 & -56 & 3344 & NS & -75 & -98 \\
\hline NW & $\begin{array}{c}0.011 \\
\mathrm{abc}\end{array}$ & $\begin{array}{c}0.003 \\
\mathrm{a}\end{array}$ & $\begin{array}{c}0.005 \\
\mathrm{ab}\end{array}$ & $\begin{array}{c}0.073 \\
\mathrm{bc}\end{array}$ & $\begin{array}{c}1.478 \\
\mathrm{~d}\end{array}$ & $\begin{array}{c}0.815 \\
\mathrm{~cd}\end{array}$ & $\begin{array}{c}0.893 \\
d\end{array}$ & $\begin{array}{l}0.993 \\
\text { cd }\end{array}$ & -29 & 943 & 21014 & 11543 & 12657 & 14086 \\
\hline SB & $\begin{array}{c}0.080 \\
\mathrm{a}\end{array}$ & $\begin{array}{c}0.067 \\
\mathrm{a}\end{array}$ & $\begin{array}{c}0.560 \\
\mathrm{abc}\end{array}$ & $\begin{array}{l}0.420 \\
\mathrm{ab}\end{array}$ & $\begin{array}{c}0.120 \\
\mathrm{a}\end{array}$ & $\begin{array}{c}1.267 \\
\mathrm{bc}\end{array}$ & $\begin{array}{c}0.393 \\
\mathrm{ab}\end{array}$ & $\begin{array}{c}2.400 \\
\mathrm{C}\end{array}$ & 662 & 471 & 63 & 1624 & 435 & 3165 \\
\hline $\mathrm{HN}$ & NS & $\begin{array}{l}0.267 \\
\mathrm{a}\end{array}$ & $\begin{array}{l}0.787 \\
\mathrm{ab}\end{array}$ & $\begin{array}{l}1.093 \\
\mathrm{ab}\end{array}$ & $\begin{array}{l}0.927 \\
\mathrm{ab}\end{array}$ & $\begin{array}{l}0.580 \\
\mathrm{ab}\end{array}$ & $\begin{array}{l}1.920 \\
b\end{array}$ & $\begin{array}{l}0.433 \\
\mathrm{ab}\end{array}$ & 195 & 309 & 247 & 117 & 619 & 62 \\
\hline GPB & $\begin{array}{c}0.057 \\
\mathrm{ab}\end{array}$ & $\begin{array}{l}0.023 \\
\mathrm{a}\end{array}$ & $\begin{array}{c}0.102 \\
\mathrm{ab}\end{array}$ & $\begin{array}{l}0.253 \\
\mathrm{ab}\end{array}$ & $\begin{array}{c}12.553 \\
b\end{array}$ & $\begin{array}{c}0.389 \\
\mathrm{ab}\end{array}$ & $\begin{array}{c}0.302 \\
\mathrm{ab}\end{array}$ & $\begin{array}{c}0.111 \\
\mathrm{a}\end{array}$ & 155 & 533 & 31283 & 873 & 655 & 178 \\
\hline $\mathrm{FB}$ & $\begin{array}{c}0.002 \\
\mathrm{a}\end{array}$ & $\begin{array}{c}0.002 \\
\mathrm{a}\end{array}$ & $\begin{array}{c}0.024 \\
\mathrm{ab}\end{array}$ & $\begin{array}{l}0.009 \\
\mathrm{ab}\end{array}$ & $\begin{array}{c}0.663 \\
\mathrm{C}\end{array}$ & $\begin{array}{l}0.020 \\
\mathrm{ab}\end{array}$ & $\begin{array}{c}0.069 \\
\mathrm{bc}\end{array}$ & $\begin{array}{l}0.067 \\
\mathrm{ab}\end{array}$ & 1100 & 350 & 33050 & 900 & 3350 & 3250 \\
\hline \multirow[t]{3}{*}{$\begin{array}{l}\text { B. Adults } \\
\text { (i) }\end{array}$} & \multicolumn{7}{|c|}{ Multiple comparisons of mean $1+$ yr scallop density (ind. $\mathrm{m}^{-2}$ ) } & (ind. $\mathrm{m}^{-2}$ ) & & & & & & \\
\hline & 2005 & 2006 & 2007 & 2008 & 2009 & 2010 & 2011 & 2012 & & & & & & \\
\hline & $\mathrm{b}$ & $\mathrm{ab}$ & a & $\mathrm{ab}$ & $\mathrm{b}$ & $\mathrm{b}$ & $\mathrm{b}$ & $\mathrm{b}$ & & & & & & \\
\hline (ii) & \multicolumn{8}{|c|}{ Mean no. $1+$ yr scallops $\mathrm{m}^{-2}$} & \multicolumn{6}{|c|}{$\begin{array}{l}\text { \% change in mean } 1+\text { yr scallop density } \\
\qquad(2005-2006) \text { to: }\end{array}$} \\
\hline & 2005 & 2006 & 2007 & 2008 & 2009 & 2010 & 2011 & 2012 & 2007 & 2008 & 2009 & 2010 & 2011 & 2012 \\
\hline $\mathrm{OH}$ & $\begin{array}{c}0.017 \\
\mathrm{ab}\end{array}$ & $\begin{array}{c}0 \\
\mathrm{ab}\end{array}$ & $\begin{array}{c}0.003 \\
\mathrm{a}\end{array}$ & $\begin{array}{c}0.051 \\
b\end{array}$ & $\begin{array}{c}0.111 \\
b\end{array}$ & $\begin{array}{c}0.176 \\
\mathrm{ab}\end{array}$ & $\begin{array}{c}0.182 \\
b\end{array}$ & $\begin{array}{l}0.093 \\
\mathrm{ab}\end{array}$ & -65 & 500 & 1206 & 1971 & 2041 & 994 \\
\hline $\mathrm{HB}$ & $\begin{array}{c}0.033 \\
\mathrm{ab}\end{array}$ & $\begin{array}{c}0.047 \\
\mathrm{ab}\end{array}$ & $\begin{array}{c}0.071 \\
\mathrm{~b}\end{array}$ & $\begin{array}{l}0.030 \\
\mathrm{ab}\end{array}$ & $\begin{array}{c}0.013 \\
a b\end{array}$ & NS & $\begin{array}{l}0 \\
\mathrm{a}\end{array}$ & $\begin{array}{c}0.033 \\
a b\end{array}$ & 78 & -25 & -67 & NS & -100 & -17 \\
\hline NW & $\begin{array}{c}0.057 \\
\mathrm{~b}\end{array}$ & $\begin{array}{c}0.010 \\
\mathrm{a}\end{array}$ & $\begin{array}{c}0.002 \\
\mathrm{a}\end{array}$ & $\begin{array}{c}0.005 \\
\mathrm{a}\end{array}$ & $\begin{array}{c}0.050 \\
\mathrm{ab}\end{array}$ & $\begin{array}{c}0.058 \\
\mathrm{ab}\end{array}$ & $\begin{array}{c}0.103 \\
\mathrm{~b}\end{array}$ & $\begin{array}{c}0.055 \\
\mathrm{~b}\end{array}$ & -94 & -85 & 49 & 73 & 207 & 64 \\
\hline SB & NS & $\begin{array}{c}0.007 \\
\mathrm{ab}\end{array}$ & $\begin{array}{c}0.013 \\
\mathrm{a}\end{array}$ & $\begin{array}{c}0.013 \\
b\end{array}$ & $\begin{array}{c}0 \\
\mathrm{ab}\end{array}$ & $\begin{array}{c}0 \\
\mathrm{ab}\end{array}$ & $\begin{array}{c}0 \\
a b\end{array}$ & $\begin{array}{c}0.020 \\
a b\end{array}$ & 271 & 271 & -100 & -100 & -100 & 471 \\
\hline $\mathrm{HN}$ & NS & NS & $\begin{array}{c}0.067 \\
a b\end{array}$ & $\begin{array}{c}0.107 \\
a b\end{array}$ & $\begin{array}{c}0.200 \\
\mathrm{~b}\end{array}$ & $\begin{array}{c}0.140 \\
\mathrm{ab}\end{array}$ & $\begin{array}{c}0.227 \\
\mathrm{~b}\end{array}$ & $\begin{array}{c}0.007 \\
\mathrm{a}\end{array}$ & & & & & & \\
\hline GPB & NS & NS & 0.091 & 0.093 & 0.100 & 0.396 & 0.273 & 0.242 & & & & & & \\
\hline $\mathrm{FB}$ & NS & NS & $\begin{array}{c}0.004 \\
\mathrm{a}\end{array}$ & $\begin{array}{c}0.078 \\
a b\end{array}$ & $\begin{array}{c}0.097 \\
a b\end{array}$ & $\begin{array}{c}0.147 \\
\mathrm{~b}\end{array}$ & $\begin{array}{c}0.004 \\
\mathrm{a}\end{array}$ & $\begin{array}{c}0.027 \\
a b\end{array}$ & & & & & & \\
\hline
\end{tabular}




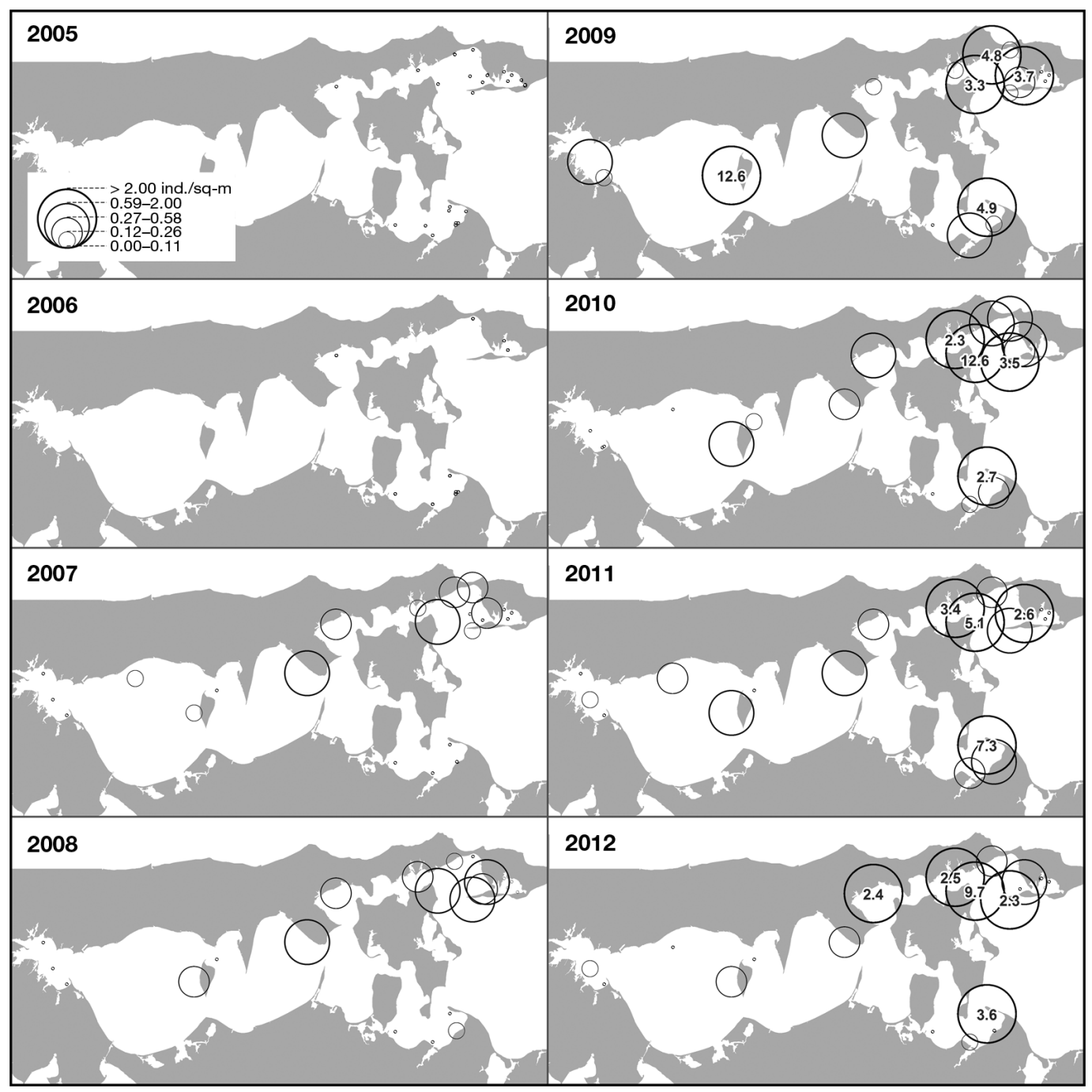

Fig. 2. Changes in mean density (ind. $\left.\mathrm{m}^{-2}\right)$ of juvenile $(0+\mathrm{yr})$ bay scallops Argopecten irradians irradians in surveyed natural populations, Peconic Bays of eastern Long Island, New York, USA, in fall; 2005-2006 = pre-restoration, 2007-2012 = following commencement of restoration. The 4 successively larger concentric circles represent noted density ranges for which the respective maximum density corresponds to projected percent fertilization success rates of 10, 20,50, and 100\% (Tettelbach et al. 2013). Mean densities $>2.00$ ind. $\mathrm{m}^{-2}$ are shown within the largest circles

0.004, respectively); in NW, the relationship was also positive but not as strong $(\mathrm{r}=0.620, \mathrm{p}=0.101)$. In $\mathrm{HB}$, there was a strong negative, linear relationship between seed scallop density and larval recruitment $(r=-0.801, p=0.030)$, while in $\mathrm{HN}$, the relationship was negative, but non-significant $(\mathrm{r}=$ $-0.354, p=0.491)$. When all embayments were considered together (i.e. whole-estuary), however, there was a strong positive correlation between seed density and $\ln \left(\right.$ mean spat bag $\left.^{-1}\right): r=0.933$, p $<0.001$ (Fig. 4A). Likewise, the correlation between wholeestuary adult density versus seed density in the prior year was highly significant $(\mathrm{r}=0.892, \mathrm{p}=$ 0.004: Fig. 4B).

\section{Temporal and spatial trends in commercial fishery landings}

Official, commercial Peconic bay scallop landings in 2008, the first year when any potential increase in harvest resulting from our restoration program could have been seen, were $\sim 3 \times$ higher (4496 kg of meats) than the average landings during the pre-restoration period (1512 kg; Fig. 5); landings steadily increased until 2010, when the harvest of $18268 \mathrm{~kg}$ of meats was $\sim 13 \times$ higher than average pre-restoration landings. Landings then decreased somewhat, but have remained relatively stable at 12631 to $15536 \mathrm{~kg}$ from 2011 to 2013 (Fig. 5), an order of magnitude greater 


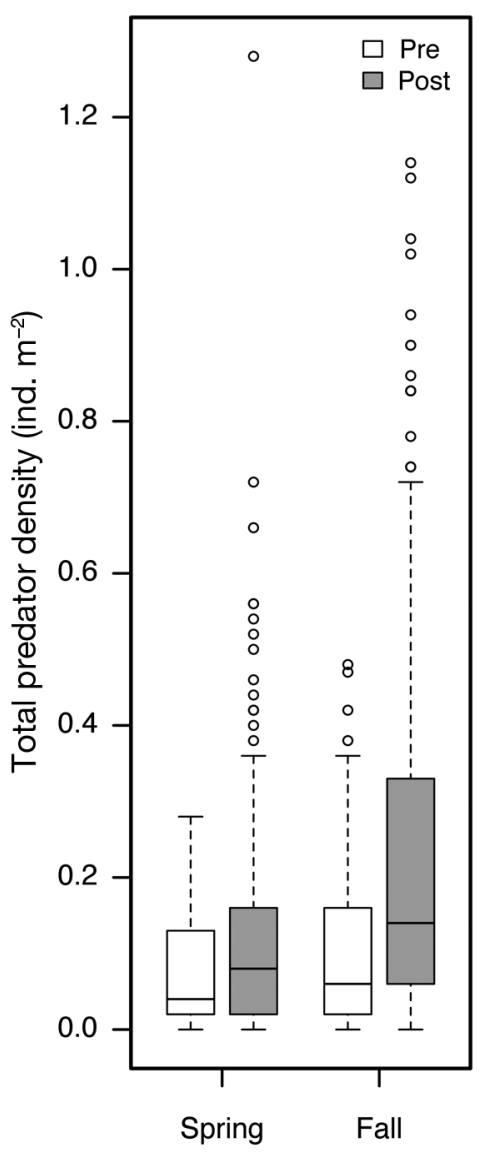

Fig. 3. Total predator densities, for all Peconic Bay sites combined, by season (spring and fall) and restoration status (preand post), 2005 to 2012. Median values are represented by a bar within the box; the 1st and 3rd quartiles, respectively, are represented by the bottom and top of the box itself; the \pm 1.5 interquartile ranges are shown by the whiskers, and outliers are shown as open circles

than the pre-restoration average. From 2008 to 2011, and in 2013, the highest landings were recorded from the Great (P2) and/or Little (P3) Peconic Bay sections in all years except 2009, when the biggest producer $(35 \%)$ was the OH/SB (P5) area (Supplement 2). The easternmost section of the Peconic estuary (Napeague) accounted for $35 \%$ of the harvest in 2012, slightly higher than GPB $(30 \%)$ in that year. Commercial landings for the entire Peconic estuary showed strong relationships with $\ln$ (mean larval recruitment) ( $\mathrm{r}=0.913, \mathrm{p}=0.003)$ and $\ln$ (seed density) ( $\mathrm{r}=0.855, \mathrm{p}=0.009)$ of the corresponding cohort (Fig. 6A,B). According to NYSDEC, the increase in dockside value of commercial bay scallop harvests from 2008 to 2013, compared to the pre-restoration period (1996-2007), was US\$2.08 million; with a
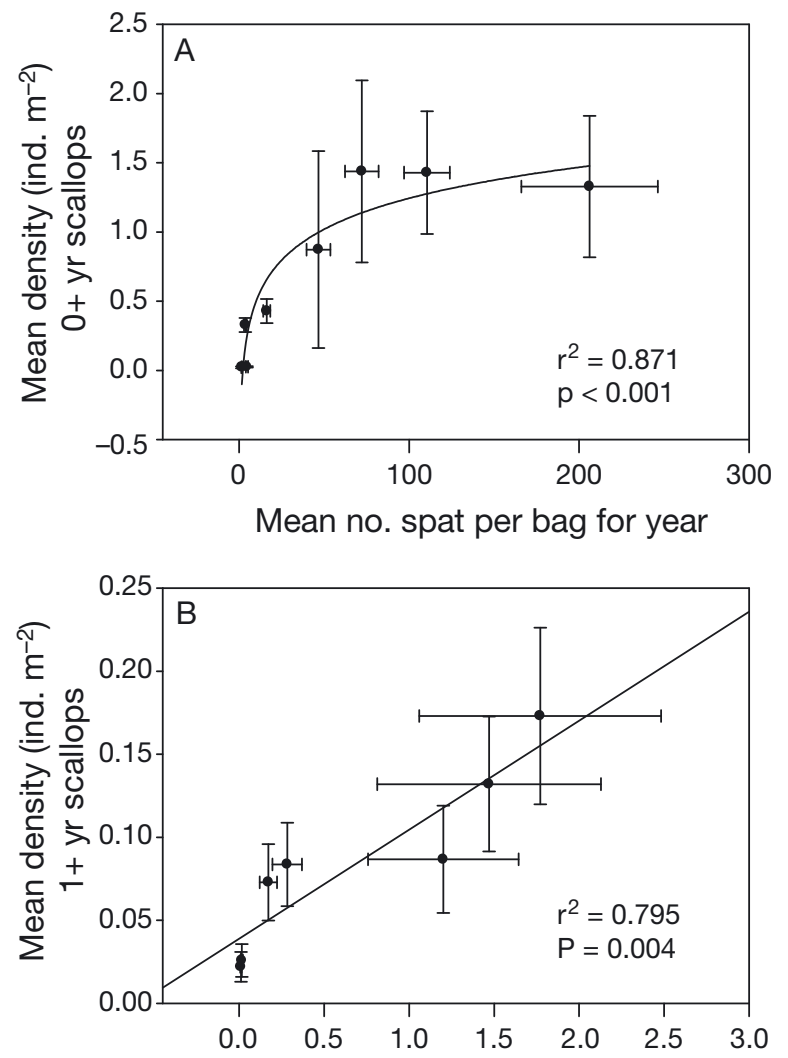

Previous year's mean density (ind. $\mathrm{m}^{-2}$ ) $0+\mathrm{yr}$ scallops

Fig. 4. Regressions, for all Peconic embayments combined, of (A) mean density of benthic juvenile $(0+$ yr) bay scallops Argopecten irradians irradians in natural populations in fall vs. larval bay scallop recruitment for the same year, 2005 to 2012: $y=-0.244+0.323(\ln x)$; and (B) mean density of adult $(1+y r)$ scallops in fall, 2006 to 2012 vs. respective mean density of benthic $0+$ yr scallops in fall of the previous year, 2005 to 2011: $y=0.039+0.066(\ln x)$

$9.88 \times$ multiplier for total increase in seafood product revenue, the economic benefit to the regional economy is calculated to be $>\$ 20$ million (Fig. 7 and Supplement 3). Using our own estimates of scallop landings, dockside revenues and economic output were valued at \$5.2 million and almost \$52 million, respectively (Fig. 7 and Supplement 3).

\section{DISCUSSION}

\section{Spatial and temporal differences in scallop populations after restoration}

The pattern of dramatic increases in $0+y r$ bay scallop densities in natural populations following commencement of intensive restoration in $\mathrm{OH}$, relative to the pre-restoration years of 2005 and 2006, paralleled 


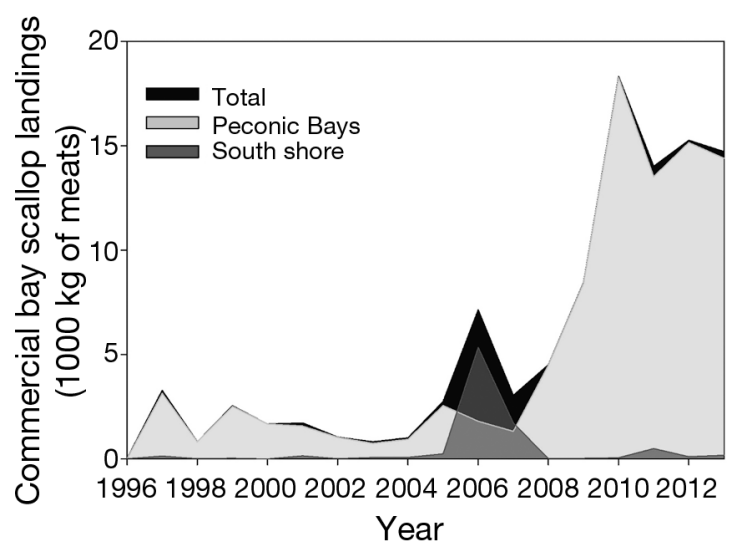

Fig. 5. Total and partitioned commercial bay scallop Argopecten irradians irradians landings for New York, 1996 to 2013. Data from NYSDEC (2014)

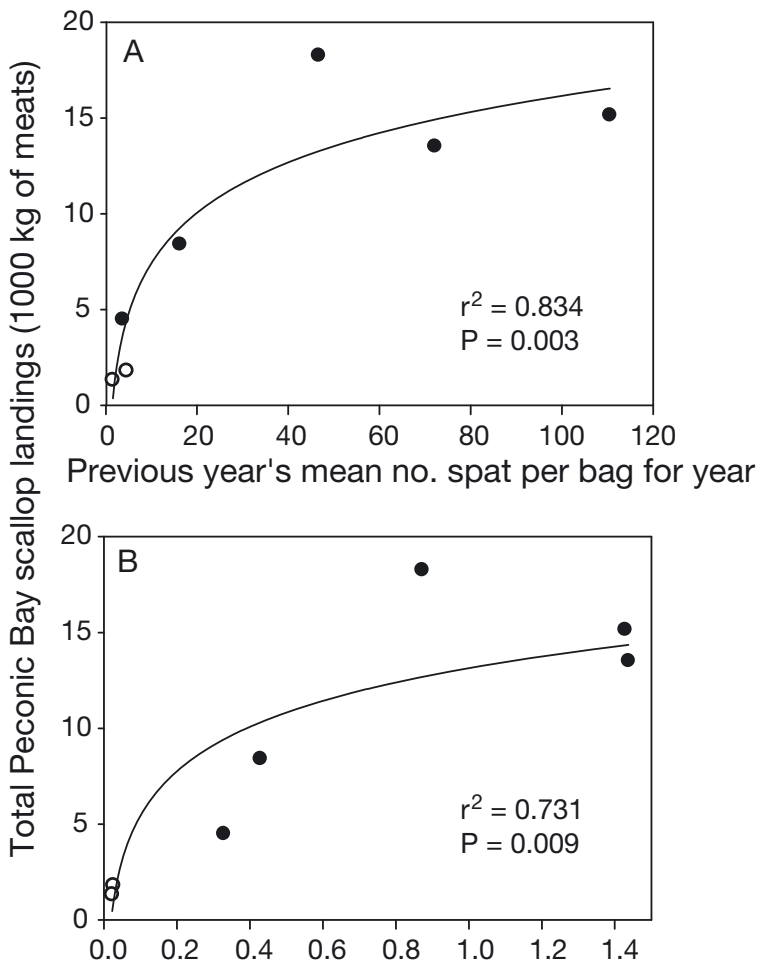

Previous year's mean density (ind. $\mathrm{m}^{-2}$ ) of $0+\mathrm{yr}$ scallops

Fig. 6. Regressions of total commercial Peconic bay scallop Argopecten irradians irradians landings, 2006 to 2012 vs. (A) the previous year's mean larval recruitment: $y=-1.32+3.79$ $(\ln x)_{i}$ and (B) the previous year's mean density of benthic juvenile $(0+y r)$ scallops in natural populations in fall: $y=$ $13.14+3.35(\ln x)$

temporal and spatial patterns of the resurgence of larval settlement resulting from spawns of planted scallops (Tettelbach et al. 2013). Initially, the increase in benthic populations was most evident in $\mathrm{OH}$, the epicenter of restoration efforts, but by 2009 increases

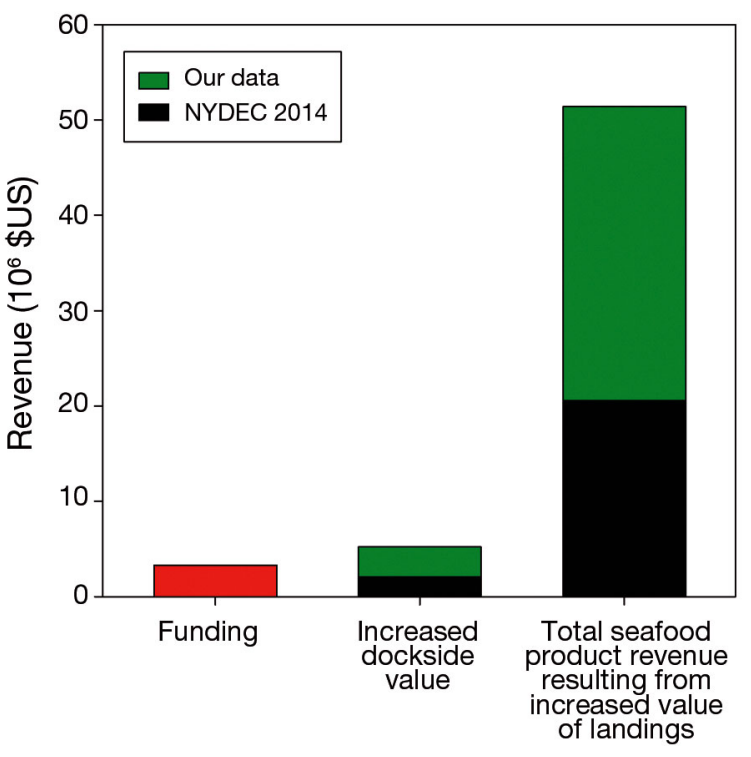

Fig. 7. Increased dockside value of commercial bay scallop harvests and total seafood product revenue resulting from increases in commercial Peconic bay scallop Argopecten irradians irradians landings (2008 to 2013: following initiation of intensive bay scallop restoration in Orient Harbor) above the average annual landings from 1996 to 2007. Project funding included to compare with returns

of $>200 \times$ (and up to $331 \times$ ) were seen throughout many of the Peconic Bays - both in embayments where scallops had been planted the prior fall and in areas where no restoration had been conducted. Aside from the archetypal population explosion of Patinopecten caurinus yessoensis in Japan following restoration efforts in the 1950s to 1960s (Ventilla 1982), population increases reported here are amongst the highest documented following molluscan restoration efforts (Arnold et al. 2005, Bell et al. 2005).

Increases in seed densities occurred at many, but not all, individual sites; this pattern likely reflects differences in levels of larval settlement (Tettelbach et al. 2013) and/or post-set survival (Eggleston \& Armstrong 1995, Gosselin \& Qian 1997, Newell et al. 2000). Marked increases in fall abundance of $0+\mathrm{yr}$ scallops in HB and FB occurred only in 2009, the year in which spawns of large numbers of surviving broodstock scallops, planted in 2008, took place; however, high numbers of FB scallops planted in 2009 survived to spawn in 2010 (Tettelbach et al. 2013) but did not yield a spike in juvenile densities that year. While larval availability tends to be slightly lower in HB than in other basins (Tettelbach et al. 2013), and larval supply is not monitored in FB, the decline of these populations after 2009 likely 
reflected the inability of the larval settlement pulse to swamp respective predator fields. For example, at some locations in HB, densities of the mud crab Dyspanopeus sayi averaged 262 ind. $\mathrm{m}^{-2}$ (as quantified using collectors) and very likely exerted intense predation on post-set scallops (Carroll et al. 2012). In addition, FB was the only site where the sea star Asterias forbesi was recorded from 2005 to 2012; this species is capable of devastating shellfish beds and restoration efforts (Tettelbach \& Wenczel 1993, Hatcher et al. 1996). The decline in 0+ yr scallop abundance in NW and GPB after 2009, and in $\mathrm{OH}$ after 2010, may reflect other potential factors (see below), but they do not reflect a decrease in larval abundance as, baywide, the mean number of spat bag $^{-1}$ was $1.47 \times$ and $2.81 \times$ higher in 2011 and 2012, respectively (S. Tettelbach unpubl. data), compared to levels in 2010 (Tettelbach et al. 2013).

Scallop population increases occurred at sites with substrate types ranging from bare sand to Crepidula fornicata or Anomia simplex barrens to moderatehigh SAV cover; while there are several limitations to our data on \% SAV cover, there was no observed effect of SAV cover on $0+$ or $1+$ yr scallop density. Thus, we conclude that the scallop population resurgence following commencement of intensive restoration was not due to a change (i.e. increase) in prevalence of SAV. Eelgrass Zostera marina has traditionally been viewed as necessary for bay scallop existence (Belding 1910, Gutsell 1930), but has continued to decline along much of the US Atlantic coast (Fonseca \& Uhrin 2009), including the Peconic Bays (Pickerell \& Schott 2004, C. Pickerell pers. comm.). However, various macroalgal species, including Gracilaria tikhvahiae, Spyridia filamentosa, and Codium fragile, may serve as alternative substrates on which Argopecten irradians irradians larvae settle (Bonal 2012) and, along with shells, provide habitat for juvenile and adult scallops (Tettelbach 1986, Hernández Cordero et al. 2012, S. Tettelbach unpubl. data). Carroll et al. (2010) showed that survival of 0+ yr scallops may be similar in Codium and eelgrass beds, while a follow-up study suggested there were no long-term deleterious effects on scallop growth or condition from associating with macroalgae (Carroll \& Peterson 2013). Clearly, at least in New York waters, eelgrass is not a prerequisite for dense sets of scallops. However, it is unknown whether the current, sparse distribution of eelgrass in the Peconic Bays has precluded a further resurgence of bay scallop populations.

Although the relationship between fall density of juvenile scallops and relative current flow was not statistically significant, it is worth noting that many of the highest $0+$ yr scallop densities were documented at individual sites with relatively high current speeds. This pattern may reflect greater delivery of larvae and/or greater survival of juveniles because of potentially reduced predator foraging efficiency at higher flow rates/turbulence (Carriker 1959, Powers \& Kittinger 2002). The one high-current site with very low benthic scallop abundance (NW2) had very low 3D structure and fluid, soft sand that was prone to shifting, as evidenced by burial of large macroalgae.

\section{Possible drivers of higher scallop abundance following restoration}

Our analyses of total densities of predators (those capable of preying on scallops $\geq 15 \mathrm{~mm}$ ) from 2005 to 2012 suggest that predator densities neither facilitated nor responded to increased on-bottom scallop densities consequent to active restoration. While we saw no differences in total predator abundance at the SWG site in NW when comparing 1990-1991 data to those of 2004-2005, Lewis et al. (1997) reported that densities of sea stars Asterias forbesi, spider crabs Libinia emarginata, and hermit crabs Pagurus spp., sampled via trawling at a total of 124 Peconic stations, were lower in 1995 than in 1979-1980. A. forbesi was once so common in the Peconic estuary that it was the major impediment to survival of bay scallop broodstock held in cages during restoration efforts of the late-1980s to early 1990s (Tettelbach \& Wenczel 1993). Thus, historically, predator densities may have been higher when Peconic bay scallop populations were more robust. If this is true, the comparatively lower predator numbers in recent years (since 1995) may have enhanced the survivability of scallops in planted and natural populations and widened the window of opportunity for current restoration efforts to succeed.

As previously described, dramatic increases in Peconic bay scallop larval supply were driven by restoration efforts, rather than coincidental changes in environmental factors (Tettelbach et al. 2013); in this study, highly significant positive correlations between benthic recruitment $(0+$ and $1+$ yr scallops) and larval supply were seen in several embayments as well as when all basins were considered together. This suggests that the main driver of the observed increase in benthic populations was the increase in larval supply, which was a direct result of restoration efforts. While this has been observed, to some extent, 
in other bay scallop restoration programs (Peterson et al. 1996, Arnold et al. 2005), none has seen as dramatic an increase over as long a time period. In the south shore bays of Long Island (e.g. Shinnecock, Moriches, and Great South Bays), where brown tide algal blooms persist (Gobler \& Sunda 2012) and where no scallop restoration efforts have been undertaken in decades, commercial landings have remained low in every year since 1995 (except 2006 in Moriches/Great South Bay: NYSDEC 2014), presumably reflecting low stock size/density and thus poor fertilization success upon spawning.

\section{Temporal and spatial differences in scallop fishery landings after restoration}

The large increase in Peconic bay scallop harvests from 2008 to 2010, and sustained harvest levels from 2011 to 2013, correlate well with the resurgence of larval recruitment (Tettelbach et al. 2013, this study) and population increases described here. Increased landings after commencement of intensive restoration are reminiscent of those that followed earlier restoration efforts in the Peconic Bays in the late 1980s/early 1990s (Tettelbach \& Wenczel 1993). Increased landings in the Napeague area from 2010 to 2013 (3.4 to $6.4 \%$ of Peconic estuary totals in 2010, 2011 , and 2013 , and $35 \%$ in 2012 , relative to $0 \%$ in most years from 1996 to 2009; NYSDEC 2014), may reflect recent scallop plantings by the Town of East Hampton (Rossi-Snook \& Dunne 2013). In supplemental transect surveys that we conducted in $\mathrm{Na}$ peague Harbor, mean 0+ yr scallop densities in November 2011 were 0.671 ind. $\mathrm{m}^{-2}$, much higher than in November of 2008 (0.005 ind. $\mathrm{m}^{-2}$ ) or 2010 $\left(0.009\right.$ ind. $\left.\mathrm{m}^{-2}\right)$. However, the proportion of 'skunk' scallops, an uncommon color morph that we reared in the hatchery for our $\mathrm{OH}$ plantings (Tettelbach et al. 2012), was almost twice as high in Napeague Harbor in 2011 compared to baseline proportions in natural populations to the west, despite the fact that the Town of East Hampton did not breed skunks in their hatchery (J. Dunne pers. comm.); this suggests that some larvae may well have been imported from outside Napeague Harbor.

The increase in Peconic bay scallop harvests from 2008 to 2013 has provided a significant infusion to the income of local baymen (NYSDEC 2014), as well as the local economy, and provides evidence of significant return on the investment in our bay scallop restoration efforts. Very few shellfish restoration programs have attained this level of return relative to program investment (Schulte et al. 2009). The economic multiplier of Kroeger (2012) is recent, but was calculated for increased finfish landings resulting from oyster reef restoration in Alabama, so it may not be the most representative; however, it is very similar to a $9.90 \times$ total multiplier effect for sales of all US commercial finfish (Southwick Associates 2013). The economic multiplier used by Karney (1991) for the Massachusetts shellfish industry was $4.5 \times$, but that calculation was done $>20$ yr ago.

While economic benefits are but one metric of restoration program success (Peterson \& Lipcius 2003), our restoration efforts have been successful on other levels. With the recent decline in commercial landings of lobsters (NOAA Fisheries 2013) and channeled whelk (K. McKown pers. comm.), two of the most valuable inshore fisheries in New York, increased scallop landings have contributed to a way of life that has been a cultural tradition on Long Island since colonial times (Matthiessen 1986). Prior to the first brown tide of 1985, the Long Island bay scallop fishery was the primary source of income for 400 to 600 full-time baymen (Tettelbach \& Wenczel 1993); while far below that number now, the resurgence in scallop landings since 2008 has seen much larger numbers of baymen participating in the fishery. We did not attempt to estimate ecosystem service benefits of higher scallop population levels (e.g. water filtration: Newell 2004), but they are likely to be significant.

\section{Components of successful bay scallop restoration}

The ultimate goal of our bay scallop restoration efforts has been to rebuild populations and the commercial fishery to pre-brown tide levels, i.e. to a sustainable annual average harvest of ca. $136078 \mathrm{~kg}$ (300000 lbs) of meats (NYSDEC 2014). We believe there are 4 critical components to successful $A$. irradians irradians restoration, requiring respective increases in: (1) larval recruitment; (2) post-settlement survival up to at least the large (>35-40 mm) juvenile $(0+$ yr) stage when bay scallops are relatively immune to most predators (Tettelbach 1986); in New York, this size is typically attained by October or November of their first year; (3) numbers and densities of $\sim 1$ yr old broodstock at the time of spawning in spring (late May to early June in New York: Bricelj et al. 1987, Tettelbach et al. 2013), which factors in the critical overwintering period (see below); and (4) survival to the harvest season, which commences in early November in many parts of the northeastern 
USA. Many/all of these components are pertinent to other types of molluscan restoration programs. Additionally, as poaching (particularly of undersized bivalves) may be detrimental to restoration efforts (Bashore et al. 2012, S. Tettelbach unpubl. data), stricter regulations and/or enforcement may be recommended. In contrast to most other fisheries and restoration efforts with different species (as discussed above), overharvesting is not considered a threat to bay scallop populations because of their unusual life history (Belding 1910, Orensanz et al. 2006).

We have shown that components 1 and 2, above, are feasible if larval production is high enough to swamp the respective larval and benthic predator fields (Taylor 1984, Tettelbach et al. 2013, this study). The critical importance of sufficient broodstock density/numbers (Petraitis \& Dudgeon 2004) and their correlation with larval settlement (Tettelbach et al. 2013), as well as the relationships of larval settlement with (1) $0+$ yr scallop density and (2) commercial fishery landings (as reported here), suggest that overcoming recruitment limitation is key to successful restoration, even while habitat for bay scallops may not be as ideal as it was historically. The importance of overwintering survival cannot be overstated; however, dramatic reductions in numbers may occur due to physical perils such as burial (Tettelbach et al. 1990) or physiological stresses associated with low water temperatures and food reserves, which are compounded by elevated metabolic demands as temperatures rise in spring (Zarnoch \& Schreibman 2008, Zarnoch \& Sclafani 2010).

The numerical and functional responses of predators which may occur with increases in prey numbers (Holling 1959, Taylor 1984) highlight the need for rebuilding bivalve populations to levels high enough to persist in the face of intense predation pressure on the life stages most vulnerable to predation: larvae and small juveniles. The slight decline in overall population densities and commercial fishery landings in 2011 to 2013, following dramatic increases from 2008 to 2010, and a level mean number of spat bag ${ }^{-1}$ in 2013 compared to 2012 (S. Tettelbach unpubl. data), may reflect a carrying capacity effect, predator responses, potential effects of recent wider occurrence of Cochlodinium polykrikoides blooms (which have been shown to cause bay scallop mortality in the laboratory: Gobler et al. 2008), or simply highlight the need for longer data sets. In the context of restoration programs, augmentation of natural populations via sustained stocking (Uki 2006) may also be an important tool for buffering populations from impacts of episodic events (particularly for a species such as the bay scallop, which is more or less semelparous). It may be generally true that restoration over multiple years is necessary to rebuild natural populations to levels well above those being planted (Tettelbach et al. 2013).

\section{Aspiring to an altered stable state}

To move a community from one stable state to another, a perturbation must be large enough to push the community out of the current domain to another stable equilibrium point; experimental evidence for movement of communities (or by inference, populations) to new alternative stable states involves a demonstration of the stability of a new state in the absence of continued manipulation (Connell \& Sousa 1983, Beisner et al. 2003). Our goal of rebuilding the decimated Peconic bay scallop metapopulation to a much higher, self-sustaining level has been attempted through a perturbation of a state variable (scallop population density). Given that our restoration efforts (the perturbation) continue, we cannot, by strict definition, conclude that the metapopulation has reached an altered stable state. However, it is clear that natural populations are driving the now higher levels of larval and benthic recruitment, because the proportion of total spawning stock and production of fertilized eggs represented by planted scallops is much lower than it was at the start (2006-2008) of intensive restoration efforts, while there have been no changes in measured environmental variables (Tettelbach et al. 2013). Bay scallops are notorious for annual fluctuations in natural population abundance and fishery landings due to their short lifespan (Belding 1910), but the relatively consistent benthic recruitment, as well as commercial landings, from 2010 to 2013 (corresponding to 4 generations) is well above 1996 to 2007 pre-restoration levels. While this may be suggestive of some degree of stability, it is uncertain how resilient current scallop population levels may be to ecological perturbations (Scheffer et al. 2001, Beisner et al. 2003), or whether our ultimate goal of reaching sustainable pre-brown tide harvests is achievable. Nevertheless, results to date have shown that substantial increases in populations, fishery landings, and revenues to fishermen and the local economy are possible over a period of just a few years if the scale, methods of deploying broodstock, and selection of sites for restoration efforts are suitable (Lenihan \& Peterson 1998, Caddy \& DeFeo 2003, Zohar et al. 2008). 
Acknowledgements. We gratefully acknowledge funding from the Suffolk County (NY) Water Quality Protection and Restoration Program and the Coastal Management Program of NY State Department of State. We are especially grateful to Vito Minei for his efforts to help launch and sustain the bay scallop restoration project. Our project has benefitted from the dedication of dozens of individuals (including many students) from Long Island University, Cornell Cooperative Extension of Suffolk County, Stony Brook-Southampton, the Southold Project for Aquaculture Training, and numerous interns and volunteers. In particular, we thank Mike Patricio, Kevin Cahill, Jeff Chagnon, Josh Clauss, Joe Hinton, Zach Schuller, Kim Tetrault, Gregg Rivara, Neal Stark, Christian Tettelbach, Linda Germana, and Kathryn Rockett. We also appreciate the assistance of Rich Langan, University of New Hampshire, and Rod Taylor, Taylor Seafood of Fairhaven (MA).

\section{LITERATURE CITED}

Arnold WS, Marelli DC, Bray CP, Harrison MH (1998) Recruitment of bay scallops Argopecten irradians in Floridan Gulf of Mexico waters: scales of coherence. Mar Ecol Prog Ser 170:143-157

Arnold WS, Blake NJ, Harrison MM, Marelli DC, Parker ML, Peters SC, Sweat DE (2005) Restoration of bay scallop (Argopecten irradians (Lamarck)) populations in Florida coastal waters: planting techniques and the growth, mortality and reproductive development of planted scallops. J Shellfish Res 24:883-904

- Bashore CJ, Lane HA, Paynter KT, Naylor M, Harding JR, Love DC (2012) Analysis of marine police citations and judicial decisions for illegal harvesting of Eastern oysters (Crassostrea virginica, Gmelin 1791) in the Maryland Portion of the Chesapeake Bay, United States, from 1959 to 2010. J Shellfish Res 31:591-598

> Beisner BE, Haydon DT, Cuddington K (2003) Alternative stable states in ecology. Front Ecol Environ 1:376-382

Belding DL (1910) The scallop fishery of Massachusetts. Mar Fish Ser No. 3. Division of Fisheries and Game, Department of Conservation, Commonwealth of Massachusetts, Boston, MA

Bell JD, Rothlisberg PC, Munro JL, Loneragan NR, Nash WJ, Ward RD, Andrew NL (2005) Restocking and stock enhancement of marine invertebrate fisheries. Adv Mar Biol 49:1-374

Bonal DM (2012) Ability and preference of Argopecten irradians irradians (Lamarack, 1819) larvae to settle on various SAV's. MSc thesis, CW Post Campus of Long Island University, Brookville, NY

Bricelj VM, Epp J, Malouf RE (1987) Intraspecific variation in reproductive and somatic growth cycles of bay scallops Argopecten irradians. Mar Ecol Prog Ser 36:123-137

Caddy JF, DeFeo O (2003) Enhancing or restoring the productivity of natural populations of shellfish and other marine invertebrate resources. Fish Tech Pap 448. FAO, Rome

Carriker MR (1959) The role of physical and biological factors in the culture of Crassostrea and Mercenaria in a salt-water pond. Ecol Monogr 29:219-266

Carroll JM, Peterson BJ (2013) Comparisons in demographic rates of bay scallops in eelgrass and the introduced alga, Codium fragile, in New York. Mar Biol 160:1451-1463

Carroll JM, Peterson BJ, Bonal D, Weinstock A, Smith CF,
Tettelbach ST (2010) Comparative survival of bay scallops in eelgrass and the introduced alga, Codium fragile, in a New York estuary. Mar Biol 157:249-259

Carroll JM, Furman BT, Tettelbach ST, Peterson BJ (2012) Balancing the edge effects budget: bay scallop settlement and loss along a seagrass edge. Ecology 93: 1637-1647

> Chavez FP, Ryan J, Lluch-Cota SE, Niquen M (2003) From anchovies to sardines and back: multidecadal change in the Pacific Ocean. Science 299:217-221

Connell JH, Sousa WP (1983) On the evidence needed to judge ecological stability or persistence. Am Nat 121: 789-824

Cosper EM, Dennison WC, Carpenter EJ, Bricelj VM and others (1987) Recurrent and persistent brown tide blooms perturb coastal marine ecosystem. Estuaries 10: 284-290

$>$ Eggleston DB, Armstrong DA (1995) Pre- and post-settlement determinants of estuarine Dungeness crab recruitment. Ecol Monogr 65:193-216

Fonseca MS, Uhrin AV (2009) The status of eelgrass, Zostera marina, as bay scallop habitat: consequences for the fishery in the Western Atlantic. Mar Fish Rev 71:20-33

Geraldi NR, Simpson M, Fegley SR, Holmlund P, Peterson $\mathrm{CH}$ (2013) Addition of juvenile oysters fails to enhance oyster reef development in Pamlico Sound. Mar Ecol Prog Ser 480:119-129

Gobler CJ, Sunda WG (2012) Ecosystem disruptive algal blooms of the brown tide species, Aureococcus anophagefferens and Aureoumbra lagunensis. Harmful Algae 14: $36-45$

Gobler CJ, Berry DL, Anderson OR, Burson A and others (2008) Characterization, dynamics, and ecological impacts of harmful Cochlodinium polykrikoides blooms on eastern Long Island, NY, USA. Harmful Algae 7: 293-307

> Goldberg R, Pereira J, Clark P (2000) Strategies for enhancement of natural bay scallop, Argopecten irradians irradians, populations: a case study in the Niantic River estuary, Connecticut, USA. Aquacult Int 8:139-158

> Gosselin LA, Qian PY (1997) Juvenile mortality in benthic marine invertebrates. Mar Ecol Prog Ser 146:265-282

> Gunderson LJ (2000) Ecological resiliency in theory and application. Annu Rev Ecol Syst 31:425-439

Gutsell JS (1930) Natural history of the bay scallop. Bull US Bur Fish 46:569-632

> Hatcher BG, Scheibling RE, Barbeau MA, Hennigar AW, Taylor LH, Windust AJ (1996) Dispersion and mortality of a population of sea scallop (Placopecten magellanicus) seeded in a tidal channel. Can J Fish Aquat Sci 53:38-54

> Hernández Cordero AL, Seitz RD, Lipcius RN, Bovery CM, Schulte DM (2012) Habitat affects survival of translocated bay scallops, Argopecten irradians concentricus (Say 1822), in lower Chesapeake Bay. Estuar Coast 35: 1340-1345

> Holling C (1959) The components of predation as revealed by a study of small mammal predation of the European pine sawfly. Can Entomol 91:293-320

Hunt HL, Scheibling RE (1997) Role of early post-settlement mortality in recruitment of benthic marine invertebrates. Mar Ecol Prog Ser 155:269-301

Karney RC (1991) Ten years of scallop culture on Martha's Vineyard. In: Shumway S, Sandifer P (eds) An international compendium of scallop biology and culture. World Aquaculture Society, Baton Rouge, LA, p 308-312 
Kimmel DG, Tarnowski M, Newell RIE (2012) Long-term (1939 to 2008) spatfall patterns in juvenile eastern oyster (Crassostrea virginica, Gmelin 1791) abundance in the Maryland portion of Chesapeake Bay. J Shellfish Res 31: 1023-1031

Knights AM, Walters K (2010) Recruit-recruit interactions, density-dependent processes and population persistence in the eastern oyster Crassostrea virginica. Mar Ecol Prog Ser 404:79-90

Knowlton N (2004) Multiple 'stable' states and the conservation of marine ecosystems. Prog Oceanogr 60:387-396

Kroeger T (2012) Dollars and sense: economic benefits and impacts from two oyster reef restoration projects in the northern Gulf of Mexico. Available at: www.nature.org/ ourinitiatives/regions/northamerica/oyster-restorationstudy-kroeger.pdf

- Lenihan HS, Peterson CH (1998) How habitat degradation through fishery disturbance enhances impacts of hypoxia on oyster reefs. Ecol Appl 8:128-140

Lessios HA, Robertson DR, Cubit JD (1984) Spread of Diadema mass mortality through the Caribbean. Science 226:335-337

Levitan DR, Petersen C (1995) Sperm limitation in the sea. Trends Ecol Evol 10:228-231

Lewis D, Kassner J, Cerrato R, Finch R (1997) An assessment of shellfish resources in the deep water areas of the Peconic estuary. Special Rep 122, Ref 97-03. Marine Sciences Research Center, Stony Brook University, Stony Brook, NY

Lewontin RC (1969) The meaning of stability. Brookhaven Symp Biol 22:13-24

Liermann M, Hilborn R (2001) Depensation: evidence, models and implications. Fish Fish 2:33-58

Matthiessen P (1986) Men's lives. Random House, New York, NY

- Menge BA, Gouhier TC, Friedenburg T, Lubchenco J (2011) Linking long-term, large-scale climatic and environmental variability to patterns of marine invertebrate recruitment: toward explaining the 'unexplained' variation. J Exp Mar Biol Ecol 400:236-249

- Neave F (1953) Principles affecting the size of pink and chum salmon populations in British Columbia. J Fish Res Board Can 9:450-491

Newell RIE (2004) Ecosystem influences of natural and cultivated populations of suspension-feeding bivalve molluscs: a review. J Shellfish Res 23:51-61

Newell RIE, Alspach GS Jr, Kennedy VS, Jacobs D (2000) Mortality of newly metamorphosed eastern oysters (Crassostrea virginica) in mesohaline Chesapeake Bay. Mar Biol 136:665-676

NOAA (National Oceanic and Atmospheric Administration) Fisheries (2013) Annual commercial landing statistics. Office of Science and Technology, NMFS Commercial Fishery Landings Data. Available at: www.st.nmfs.noaa. gov/commercial-fisheries/commercial-landings/annuallandings/

NYSDEC (New York State Department of Environmental Conservation) (2014) Annual commercial shellfish landings for New York state, 1946-2010, and rainfall records for eastern Long Island locations, 1996-2010. NYSDEC, East Setauket, NY

Orensanz JM, Parma AM, Turk T, Valero J (2006) Dynamics, assessment and management of exploited natural populations. In: Shumway SE, Parsons GJ (eds) Scallops: biology, ecology and aquaculture, 2nd edn. Elsevier, New
York, NY, p 765-868

Paine RT (1966) Food web complexity and species diversity. Am Nat 100:65-75

Peterson CH (2002) Recruitment overfishing in a bivalve mollusc fishery: hard clams (Mercenaria mercenaria) in North Carolina. Can J Fish Aquat Sci 59:96-104

> Peterson CH, Lipcius RN (2003) Conceptual progress towards predicting quantitative ecosystem benefits of ecological restorations. Mar Ecol Prog Ser 264:297-307

$>$ Peterson CH, Summerson HC (1992) Basin-scale coherence of population dynamics of an exploited marine invertebrate, the bay scallop: implications of recruitment limitation. Mar Ecol Prog Ser 90:257-272

Peterson CH, Summerson HC, Luettich RA Jr (1996) Response of bay scallops to spawner transplants: a test of recruitment limitation. Mar Ecol Prog Ser 132:93-107

Petraitis PS, Dudgeon SR (2004) Detection of alternative stable states in marine communities. J Exp Mar Biol Ecol 300:343-371

Pickerell C, Schott S (2004) Peconic Estuary Program long term eelgrass monitoring program: eelgrass trends analysis report: 1997-2002. Prepared for the Peconic Estuary Program Marine Program. Cornell Cooperative Extension, Riverhead, NY

Powers SP, Kittinger JN (2002) Hydrodynamic mediation of predator-prey interactions: differential patterns of prey susceptibility and predator success explained by variation in water flow. J Exp Mar Biol Ecol 273:171-187

Rossi-Snook K, Dunne J (2013) East Hampton Town Shellfish Hatchery 2012 Annual Report and 2013 Operating Plan, East Hampton, NY

Roughgarden J, Iwasa Y (1986) Dynamics of a meta-population with space-limited subpopulation. Theor Popul Biol 29:235-261

Scheffer M, Carpenter S, Foley JA, Folke C, Walker B (2001) Catastrophic shifts in ecosystems. Nature 413:591-596

Schulte DM, Burke RP, Lipcius RN (2009) Unprecedented restoration of a native oyster metapopulation. Science 325:1124-1128

Southwick Associates (2013) Comparing NOAA's recreational and commercial fishing economic data. Report prepared for the American Sportfishing Association. Available at: http://asafishing.org/uploads/Comparing_ Recreational_and_Commercial_Marine_Fishing_Data_ Report_May_2013.pdf

> Suding KN, Gross KL, Houseman GR (2004) Alternative states and positive feedbacks in restoration ecology. Trends Ecol Evol 19:46-53

Summerson HC, Peterson CH (1990) Recruitment failure of the bay scallop, Argopecten irradians concentricus, during the first red tide, Ptychodiscus brevis, outbreak recorded in North Carolina. Estuaries 13:322-331

Taylor RJ (1984) Predation. Chapman \& Hall, New York, NY

Tettelbach ST (1986) Dynamics of crustacean predation on the northern bay scallop, Argopecten irradians irradians. $\mathrm{PhD}$ dissertation, University of Connecticut, Storrs, CT

Tettelbach ST, Smith CF (2009) Bay scallop restoration in New York. Ecol Res 27:20-22

Tettelbach ST, Wenczel P (1993) Reseeding efforts and the status of bay scallop Argopecten irradians (Lamarck, 1819) populations in New York following the appearance of 'brown tide' algal blooms. J Shellfish Res 12: 423-431

Tettelbach ST, Smith CF, Kaldy JE III, Arroll TW, Denson MR (1990) Burial of transplanted bay scallops Argo- 
pecten irradians irradians (Lamarck, 1819) in winter. J Shellfish Res 9:127-134

Tettelbach ST, Barnes D, Aldred J, Rivara G and others (2011) Utility of high density plantings in bay scallop, Argopecten irradians irradians, restoration. Aquacult Int 19:715-739

Tettelbach ST, Smith CF, Europe JR, Cahill K and others (2012) Bringing 'em back: bay scallop restoration in the Peconic Bays, Long Island, New York. Paper presented at the 32nd Annual Milford Aquaculture Seminar. J Shellfish Res 31:228

Tettelbach ST, Peterson BJ, Carroll JM, Hughes SWT and others (2013) Priming the larval pump: resurgence of bay scallop recruitment following initiation of intensive restoration efforts. Mar Ecol Prog Ser 478:153-172

Uki N (2006) Stock enhancement of the Japanese scallop Patinopecten yessoensis in Hokkaido. Fish Res 80:62-66 van Oppen MJH, Lough JM (eds) (2009) Coral bleaching: patterns, processes, causes and consequences. SpringerVerlag, Berlin

Editorial responsibility: Romuald Lipcius, Gloucester Point, Virginia, USA
Ventilla RF (1982) The scallop industry in Japan. Adv Mar Biol 20:309-382

Vermeij GJ (1995) Economics, volcanoes and Phanerozoic revolutions. Paleobiology 21:125-152

Weinstock A (2010) Predation on the northern bay scallop Argopecten irradians irradians (Lamarck, 1819) by scup, Stenotomus chrysops (Linnaeus, 1766): effects of predator/prey size and substrate. MSc thesis, Long Island University, Brookville, NY

Zarnoch CB, Schreibman MP (2008) Influence of temperature and food availability on the biochemical composition and mortality of juvenile Mercenaria mercenaria (L.) during the over-winter period. Aquaculture 274:281-291

Zarnoch CB, Sclafani M (2010) Overwinter mortality and spring growth in selected and non-selected juvenile Mercenaria mercenaria. Aquat Biol 11:53-63

Zohar Y, Hines AH, Zmora O, Johnson EG and others (2008) The Chesapeake Bay blue crab (Callinectes sapidus): a multidisciplinary approach to responsible stock replenishment. Rev Fish Sci 16:24-34

Submitted: September 1, 2014; Accepted: February 27, 2015 Proofs received from author(s): May 21, 2015 